\title{
East and West Comparative Literature and Culture: A Review Article of New Work by Lee and Collected Volumes by Lee and Syrokomla-Stefanowska
}

\author{
Xiaoyi Zhou \\ Peking University
}

Follow this and additional works at: https://docs.lib.purdue.edu/clcweb

C.

Part of the Comparative Literature Commons, and the Critical and Cultural Studies Commons

Dedicated to the dissemination of scholarly and professional information, Purdue University Press selects, develops, and distributes quality resources in several key subject areas for which its parent university is famous, including business, technology, health, veterinary medicine, and other selected disciplines in the humanities and sciences.

CLCWeb: Comparative Literature and Culture, the peer-reviewed, full-text, and open-access learned journal in the humanities and social sciences, publishes new scholarship following tenets of the discipline of comparative literature and the field of cultural studies designated as "comparative cultural studies." Publications in the journal are indexed in the Annual Bibliography of English Language and Literature (Chadwyck-Healey), the Arts and Humanities Citation Index (Thomson Reuters ISI), the Humanities Index (Wilson), Humanities International Complete (EBSCO), the International Bibliography of the Modern Language Association of America, and Scopus (Elsevier). The journal is affiliated with the Purdue University Press monograph series of Books in Comparative Cultural Studies. Contact: <clcweb@purdue.edu>

\section{Recommended Citation}

Zhou, Xiaoyi. "East and West Comparative Literature and Culture: A Review Article of New Work by Lee and Collected Volumes by Lee and Syrokomla-Stefanowska." CLCWeb: Comparative Literature and Culture 2.3 (2000):

<https://doi.org/10.7771/1481-4374.1083>

This text has been double-blind peer reviewed by $2+1$ experts in the field.

The above text, published by Purdue University Press @Purdue University, has been downloaded 7076 times as of 11/ 07/19. Note: the download counts of the journal's material are since Issue 9.1 (March 2007), since the journal's format in pdf (instead of in html 1999-2007).

This document has been made available through Purdue e-Pubs, a service of the Purdue University Libraries. Please contact epubs@purdue.edu for additional information.

This is an Open Access journal. This means that it uses a funding model that does not charge readers or their institutions for access. Readers may freely read, download, copy, distribute, print, search, or link to the full texts of articles. This journal is covered under the CC BY-NC-ND license. 


\section{PURDUE}

UNIVERSITY PRESS <http://www.thepress.purdue.edu>

\section{CLCWeb: Comparative Literature and Culture}

ISSN 1481-4374 <http://docs.lib.purdue.edu/clcweb> Purdue University Press (CPurdue University

CLCWeb: Comparative Literature and Culture, the peer-reviewed, full-text, and open-access learned journal in the humanities and social sciences, publishes new scholarship following tenets of the discipline of comparative literature and the field of cultural studies designated as "comparative cultural studies." In addition to the publication of articles, the journal publishes review articles of scholarly books and publishes research material in its Library Series. Publications in the journal are indexed in the Annual Bibliography of English Language and Literature (Chadwyck-Healey), the Arts and Humanities Citation Index (Thomson Reuters ISI), the Humanities Index (Wilson), Humanities International Complete (EBSCO), the International Bibliography of the Modern Langua-ge Association of America, and Scopus (Elsevier). The journal is affiliated with the Purdue University

Press monog-raph series of Books in Comparative Cultural Studies. Contact: <clcweb@purdue.edu>

CLCWeb Volume 2 Issue 3 (September 2000) Book Review Article Xiaoyi Zhou,

"East and West Comparative Literature and Culture: A Review Article of New Work by Lee and Collected Volumes by Lee and Syrokomla-Stefanowska" <http://docs.lib.purdue.edu/clcweb/vol2/iss3/9>

Contents of CLCWeb: Comparative Literature and Culture 2.3 (2000)

$<<$ http://docs.lib.purdue.edu/clcweb/vol2/iss3/>> 


\section{Xiaoyi ZHOU}

\section{East and West Comparative Literature and Culture: A Review Article of New Work by Lee and Collected Volumes by Lee and Syrokomla-Stefanowska}

This review article is about volumes published in the University of Sydney World Literature Series (published by Wild Peony Press and distributed by the University of Hawaii Press), Sang-Kyong Lee, East Asia and America: Encounters in Drama and Theatre (2000), Mabel Lee and A.D. Syrokomla-Stefanowska, eds., Literary Intercrossings: East Asia and the West (1998), and Mabel Lee and Meng Hua, eds., Cultural Dialogue and Misreading (1997).

Cultural Dialogue and Misreading, the first of this new series of scholarship in comparative and world literature, is a wide-ranging collection of articles, selected papers from an international conference, "Cultural Dialogue and Cultural Misreading," held in October 1995 at the Resarch Institute for Comparative Literature, Peking University. The invitational conference was organized in conjunction with the annual meeting of the members of the executive council of the ICLA: International Comparative Literature Association. The volume is divided into three sections, "Dialogue," "Misreading," and "Identity," and the articles address a wide variety of topical issues in comparative literature and cultural studies including such as globalization and cultural identity in the Third World, cultural relativism and cultural universalism, postmodernism, translation studies, multiculturalism and multicultural literatures, and imagology. The general perspective of the papers is to suggest that as cultural interaction on a global scale grows, literary research must also expand its horizon; the traditional pursuits of literary research -- such as literary exegesis, the identification and evaluation of canonical texts, and translation -- must reposition themselves against this broader backdrop. The theme of cultural dialogue and exchange and cultural relativism is discussed by Gerald Gillespie, Paul Cornea, Eduardo F. Coutinho, Amiya Dev, Mario Valdés, Douwe Fokkema, Ersu Ding, Yue Daiyun, Han Jiaming, Gu Zhengkun, Qian Zhongwen, Z.I. Siaflekis; the theme of multicuralism and its problematics are discussed by Song Weije, Steven $P$. Sondrup, M. Szegedy-Maszák, and Steven Tötösy de Zepetnek; translation studies are discussed by Shen Dan, E.D. Blodgett, and Theresa Hyun; the theme of identity and literature and culture are discussed by Meng Hua, Holger Klein, Sylvie André, and Jean-Marc Moura; and the context of dialogue, exchange, and identity with regard to specific texts and authors is discussed by Raoul David Findeisen, Mabel Lee, Qin Haiying, Béatrice Didier, John Neubauer, Wang Yiman, Tanaka Takaaki, Manfred Schmeling, Maria Alzira Seixo, Jean Bessière, Tao Jie, Holger Klein, and Wade Kelson; theoretical perspectives in the context of culture, literature, and identity are discussed by John Boening, Walter F. Veit, Hendrik van Gorp, Zhang Yinde, Muriel Detrie, Margarida L. Losa, Anton Kaes, Svend Erik Larsen, Rien T. Segers, Maria Elena de Valdés, Tania Franco Carvalhal, Guo Hongan, and Cao Shunqing. Again, of importance is that all contributions present a global, international, and/or comparative perspective.

Of particular interest to me are papers dealing with the problematics of the so-called "grand narrative" and the "petit narratives" of individual authors' works. Among these are the contributions of Mabel Lee, Meng Hua, and Raoul David Findeisen: Their essays are refreshingly original, offering new research and new perspectives. Mabel Lee's paper takes as its starting point the image of masks, using this theme to explore the concepts of reality developed in the poetics of Octavio Paz and Yang Lian. Meng's essay analyses the production and development of images of the "West" in Chinese literature from the mid-nineteenth century. Through a dissection of the emergence and evolution of the Chinese stereotype of the "foreign devil" (yang guizi) Meng demonstrates how one country's images of foreign countries are a product of that country's own culture and politics. Findeisen also proceeds by exploring the bonds between apparently distant points: His article examines the internal bonds between Gabriele d'Annunzio and Xu Zhimo through the theme of flight. Their shared yearning for the experience of flight embodies, in Findeisen's view, the emergent surrealist tendency in modernist literature. In sum, the essays found in this volume are rich in ideas and traverse a broad intellectual and geographic territory.

The second volume in the series is Literary Intercrossings: East Asia and the West and it is also a collection of papers, volume five from the series of six volumes with selected papers presented 
at the XIVth Congress of the ICLA: International Comparative Literature Association held at the University of Alberta in August 1994. Among the questions addressed in its pages are the dissemination and influence of Asian literatures in Europe and America, comparisons between Eastern and Western thought and literature: For example, comparisons of Wang Guowei with Kant (Liu Qingzhang), and of Taoism with Montaigne (Xiaojuan Wang), and concepts of the self in Chinese and Western literature (Xiaojuan Wang). A considerable number of the essays address this last issue. Linda Wong's paper examines the reception of Dante Rossetti's work by the modern Chinese poets and critics Xu Zhimo and Wen Yiduo. She argues that both Xu and Wen pursued a concept of the self which was modern, autonomous and self-controlling. Wong points out that in fact they borrowed from Western Romanticism to resist Chinese tradition and pursue a particular vision of modernity. Terry Siu-han Yip's paper also examines the impact of the Western concepts of self on Chinese modern thought, focusing on their questioning of the traditional Chinese concept of self dependent on set roles for members of societies and families. Other papers dealing with a variety of themes concerning Chinese, Japanese, and Korean texts and contexts, often in comparison with Western texts and contexts are by Christopher Gibbins, Nina Lluhi de Hasegawa, Huang Yuhuang, Maria Luisa Leal, Sang-Kyong Lee, Sangok Lee, Sang-Ran Lee, Midori Matsui, Etsuko Nakayama, Hiroko Odagiri, Yuzo Ota, Qian Linsen, Sugawara Katsuya, Jun'ichiro Takachi, Janet A. Walker, Terry Siu-han Yip, and Ho-Byeong Yoon.

The third book in this series, East Asia and America: Encounters in Drama and Theatre is a richly-documented and detailed monograph by Sang-Kyong Lee (University of Vienna). He focuses on the influence on American culture by the Chinese and Japanese cultures, and, to a lesser degree, by Korean culture. Lee's focus is on drama but along the way he covers many other themes and perspectives in and of art. Lee first sets the scene with an introductory examination of the West's reception of Eastern culture. The author's command of a large volume of material in English, French, German, Korean, and Japanese makes this an impressively comprehensive overview of his topic. Lee covers the influence of Chinese philosophy and literature in Europe, the spread of Japanese painting techniques to the West, the influence of Japanese Noh drama on European and American theater, and performances by Korean musicians in Europe in the second half of the twentieth century. The second part of East Asia and America: Encounters in Drama and Theatre is a series of studies of specific authors. Lee has chosen to focus on several dominant figures in twentieth-century American literature: Ezra Pound, T.S. Eliot, Eugene O'Neill, and Thornton Wilder, and he offers a detailed analysis of the Eastern cultural elements in their works. He describes the influence of the "spiritual world of the East" -- mysticism, Buddhism, Hinduism, Taoism -- on the drama of T.S. Eliot and Eugene O'Neill, and also the influence of Japanese haiku on Ezra Pound's "imagism." According to Lee's analysis, the principle of "poetry as picture" embodied in East Asian poetry played a crucial role in Pound's entire creative process. The third part of Lee's study examines the influence of Japanese culture on American drama, choreography, and music. For example, Lee highlights the painterly qualities in Robert Wilson's "Theater of Images" and their connections with Japanese theater. He points out Wilson's appreciation of Japanese gardens and of "non-verbal communication" and points out Wilson's views of Japanese culture. Similarly, in his analysis of Stephen Sondheim's musical Pacific Overtures Lee argues that it "combines Western features with Eastern elements." A final section of the book then summarizes the history of teaching and research of Japanese theater in American academic institutions.

Lee's study applies research techniques largely similar to the ones used in the two preceding books -- traditional comparative literature techniques for studying influence. But we also need to ask the question of how this influence and interaction is produced. In his discussion of Pacific Overtures, Lee addresses not only the Eastern elements in their artistry, but also the question of cultural identity in East Asian countries. Pacific Overtures expresses, Lee proposes, the contradictions between Japan's Westernization and modernization and its national cultural identity. This implies a dichotomy between tradition and modernity and between backwardness and progress. In this theoretical framework the impact of the West on the East is explained in these terms: Western culture was expanded into, disseminated in, and spread throughout East Asian countries as an accompaniment to modernization. Consequently, traditional culture underwent a 
painful process of transmutation in the wake of the break-up of pre-modern society. I should like to point out that this argumentation is presented also in most of the papers in Cultural Dialogue and Misreading and Literary Intercrossings: East Asia and the West, for example in the various discussion of the concept of self. But this model is also problematic, in theory as well as when judged from historical facts. Theoretically, it is a symptom of Western-centrism in comparative literary research because it examines modernization as an endogenous product of the West. But without the opening of communication and dialogue between East and West, without the markets of the East, and without the silver of Latin America or the cheap labour and resources in many parts of the non-Western parts of the world, the West's modernization and industrial revolution would likely not have occurred. In comparative literature, the tradition/modernization model can partially explain the impact of Western culture on Eastern culture but it can offer no persuasive explanation for the influence of Eastern culture on Western culture. For instance, how can the dichotomous model of tradition and the East versus modernity and the West explain the crucial influence of Confucianism on eighteenth-century French enlightenment? How can it explain the formative influence of traditional Japanese art on the rise of aestheticism in late nineteenth century France and England, or the influence of Eastern literatures on twentieth-century American modernist poetry and drama? Thus, these dichotomous models are themselves in need of interrogation and their ideological character should also be noted.

Yet, setting aside these questions of methodology and models, all of these studies of interaction between Eastern and Western culture have a major social significance: Their significance transcends the content of the research itself. Just as a quotation from Gilles Deleuze and Félix Guattari cited in Christopher Gibbins' paper in Literary Intercrossings: East Asia and the West puts it, in minor and exile literatures cross-cultural expressions provide certain "lines of escape" (1). That is, these studies offer a broad understanding of interactions between different cultures, and, more importantly, they illuminate the cultural hegemony of mainstream literature, and they constitute a subversion of and challenge to the uniform ideology derived from this mainstream literature and its processes. Although some of the papers in the collected volumes are in need of both substance and style in my opinion, they at the same time raise many issues for further attention and elaboration. In sum, all volumes of the University of Sydney World Literature Series demonstrate the importance and value of the field of comparative literature and culture and represent an encouraging sign to both scholars studying non-Western literatures and cultures and scholars working in non-Western cultures.

Reviewer's profile: Xiaoyi Zhou teaches English literature at Peking University. He received his Ph.D. from Lancaster University in 1993 and was Research Fellow at the University of Hong Kong between 1997 and 2000. He is the author of Beyond Aestheticism: Oscar Wilde and Consumer Society (1996). Zhou has published widely on English and comparative literature, literary theory, and cultural studies. E-mail: <xyzhou@pku.edu.cn>. 